\title{
KAJIAN YURIDIS PELIMPAHAN KEWENANGAN DOKTER UMUM KEPADA BIDAN DALAM PELAYANAN OBSTETRI DAN NEONATAL EMERGENSI DASAR DI PUSKESMAS GANDRUNGMANGU SATU \\ Oleh: Pentadi Teguh Setyianta ${ }^{44}$
}

\begin{abstract}
Health is a basic human right and one of the elements of well-being which must be realized in accordance with the ideals of the nation of Indonesia. The number of doctors who are a little bit in some areas cause most doctor who conducts independent practice or physician clinics delegate or grant authority in conducting medical practice to the health workforce personnel have different competencies, such as Midwives.

The purpose of the study to analyse the provisions of the medical act of authority pelimpahan conducted by doctors at the clinic. Methods of Juridical Normative approach is used, the type of research Preskripsi. Data sources used are: primary Data and Secondary Data. Method of Data collection is done with the study of librarianship, research results are analyzed further Normative Qualitative.

The limitations of medical personnel (doctor) give rise to situations that require that the nurse or midwife do treatment or perform an action that is not a medical authority. Basic health services at the Clinic could not be fully implemented by the doctor, so many services/medical action which is the authority of doctors carried out by nurses/midwives, medical services at health centers also Roving as well as Clinics Maid only served by nurses/midwives. Legally, labor nurses/midwives do not have the authority to carry out medical services.

Keywords: Health, Clinic, Doctor
\end{abstract}

\section{ABSTRAK}

Kesehatan merupakan hak asasi manusia dan salah satu unsur kesejahteraan yang harus diwujudkan sesuai dengan cita-cita bangsa Indonesia. Jumlah dokter yang sedikit di beberapa daerah menyebabkan seringnya dokter yang menyelenggarakan praktik mandiri atau dokter puskesmas mendelegasikan atau melimpahkan kewenangan dalam melakukan praktik kedokteran kepada tenaga tenaga kesehatan yang memiliki kompetensi yang berbeda, seperti Bidan.

Tujuan penelitian ntuk menganalisis ketentuan tentang pelimpahan kewenangan tindakan kedokteran yang dilakukan oleh dokter di Puskesmas. Metode Pendekatan

yang digunakan Yuridis Normatif, dengan tipe Penelitian Preskripsi. Sumber Data yang dipakai adalah: Data Primer dan Data Sekunder. Metode Pengumpulan Data dilakukan dengan studi kepustakaan, Hasil penelitian selanjutnya dianalisis secara Normatif Kualitatif.

Keterbatasan tenaga medis (dokter) menimbulkan situasi yang mengharuskan perawat atau bidan melakukan tindakan pengobatan atau melakukan tindakan medis yang bukan wewenangnya. Pelayanan kesehatan dasar di Puskesmas tidak bisa sepenuhnya dilaksanakan oleh dokter, sehingga banyak pelayanan/tindakan medik yang

${ }^{44}$ Kepala UPT Puskesman Gandrungmangu I, Cilacap. HP. 081327398448 
merupakan kewenangan dokter dikerjakan oleh perawat/bidan, juga pelayanan medik di Puskesmas Keliling maupun Puskesmas Pembantu hanya dilayani oleh tenaga perawat/bidan. Secara yuridis, tenaga perawat/bidan tidak mempunyai kewenangan untuk melaksanakan pelayanan medik.

Kata Kunci: kesehatan, klinik, dokter

\section{A. Pendahuluan}

Undang-Undang Dasar Negara

Republik Indonesia Tahun 1945 mencantumkan dengan jelas cita-cita bangsa Indonesia yang sekaligus merupakan tujuan nasional bangsa Indonesia. Tujuan nasional tersebut adalah melindungi segenap bangsa Indonesia dan seluruh tumpah darah Indonesia dan memajukan kesejahteraan umum, mencerdaskan kehidupan bangsa dan ikut melaksanakan ketertiban dunia yang berdasarkan kemerdekaan perdamaian abadi serta keadilan sosial. Untuk mencapai tujuan nasional tersebut diselenggarakanlah upaya pembangunan yang berkesinambungan yang merupakan suatu rangkaian pembangunan yang menyeluruh terarah dan terpadu, termasuk di antaranya pembangunan kesehatan.

Kesehatan merupakan hak asasi manusia dan salah satu unsur kesejahteraan yang harus diwujudkan sesuai dengan cita-cita bangsa Indonesia sebagaimana dimaksud dalam Pancasila dan Pembukaan Undang-Undang Dasar Negara Republik Indonesia Tahun 1945, oleh karena itu setiap kegiatan dan upaya untuk meningkatkan derajat kesehatan masyarakat yang setinggi-tingginya dilaksanakan berdasarkan prinsip nondiskriminatif, partisipatif, perlindungan, dan berkelanjutan yang sangat penting artinya bagi pembentukan sumber daya manusia Indonesia, peningkatan ketahanan dan daya saing bangsa, serta pembangunan nasional. ${ }^{45}$

\section{Perserikatan Bangsa-Bangsa} (PBB) pada tahun 1948 telah menetapkan Universal Declaration of Human Rights, yang di dalamnya mengatur hak atas kesehatan. Dalam Pasal 25 dinyatakan:

"Setiap orang berhak atas taraf hidup yang menjamin kesehatan dan kesejahteraan untuk dirinya dan keluarganya, termasuk pangan, pakaian, perumahan dan perawatan kesehatan..."

Sejalan dengan itu, Konstitusi World Health Organization (WHO) 1948 telah menegaskan pula bahwa "memperoleh derajat kesehatan yang setinggi- tingginya adalah suatu hak asasi bagi setiap orang" (the enjoyment of the highestattainable standard of health is one of the fundamental rights of every human being). Istilah yang digunakan bukan "human rights", tetapi

${ }^{45}$ Penjelasan Umum UU No. 36 Tahun 2009 tentang Kesehatan 
1025 | Jurnal Idea Hukum

Vol. 4 No. 2 Oktober 2018

Magister Hukum Fakultas Hukum Universitas Jenderal Soedirman

"fundamental rights", yang kalau
diterjemahkan langsung
Bahasalndonesia menjadi "Hak hak
Dasar".

Upaya untuk meningkatkan derajat kesehatan yang setinggitingginya pada mulanya berupa upaya penyembuhan penyakit, kemudian secara berangsur-angsur berkembang ke arah keterpaduan upaya kesehatan untuk seluruh masyarakat dengan mengikutsertakan masyarakat secara luas yang mencakup upaya promotif, preventif, kuratif, dan rehabilitatif yang bersifat menyeluruh terpadu dan berkesinambungan. Dokter merupakan salah satu profesi yang memiliki peranan penting dalam pembangunan kesehatan. Dokter sebagai salah satu komponen utama pemberi pelayanan kesehatan kepada masyarakat mempunyai peranan yang sangat penting karena terkait langsung dengan pemberian pelayanan kesehatan dan mutu pelayanan yang diberikan.

Landasan utama bagi dokter untuk dapat melakukan tindakan medis terhadap orang lain adalah ilmu pengetahuan, teknologi, dan kompetensi yang dimiliki, yang diperoleh melalui pendidikan dan pelatihan. Dokter dengan perangkat keilmuan yang dimilikinya mempunyai karakteristik yang khas. Kekhasannya ini terlihat dari pembenaran yang diberikan oleh hukum yaitu diperkenankannya melakukan tindakan medis terhadap tubuh manusia dalam upaya memelihara dan meningkatkan derajat kesehatan. Dokter adalah seorang tenaga kesehatan yang memberikan pelayanan medis kepada pasien yang membutuhkan pengobatan.

Pasal 1 Ayat (11) UU 29/2004 tentang Praktik Kedokteran, yang disebut profesi dokter atau kedokteran gigi adalah suatu pekerjaan kedokteran atau kedokteran gigi yang dilaksanakan berdasarkan suatu keilmuan, kompetensi yang diperoleh melalui pendidikan yang berjenjang, dan kode etik yang bersifat melayani masyarakat. Seorang dokter harus memahami ketentuan hukum yang berlaku dalam pelaksanaan profesinya termasuk didalamnya tentang pemahaman hakhak dan kewajiban dalam menjalankan profesi sebagai dokter. Kesadaran dokter terhadap kewajiban hukumnya baik terhadap diri sendiri maupun terhadap orang lain dalam menjalankan profesinya harus benar-benar dipahami dokter sebagai pengemban hak dan kewajiban.

Menurut Veronika Komalawati, ${ }^{46}$ Dokter sebagai pengemban profesi adalah orang yang mengabdikan diri dalam bidang kesehatan serta memiliki pengetahuan dan keterampilan melalui pendidikan di bidang kedokteran yang berwenang untuk melakukan upaya

46 Veronika Komalawati, 2002, Peranan Informed Consent dalam Transaksi Terapeuti Studi Tinjauan Yuridis, Cetakan Kedua, Citra Aditya Bhakti, Bandung, hal. 17 
kesehatan. Dokter sebagai pengemban profesi dalam pelayanan kesehatan, dibebani pula dengan kewajibankewajiban sebagaimana dikemukakan oleh Alexandra Indriyanti Dewi ${ }^{47}$ antara lain sebagai berikut :

1. Setiap dokter harus menjunjung tinggi, menghayati dan mengamalkan sumpah kedokteran;

2. Setiap dokter harus senantiasa melakukan profesinya menurut ukuran tertinggi;

3. Dalam melakukan pekerjaan kedokterannya, dokter tidak boleh dipengaruhi oleh pertimbangan keuntungan pribadi;

4. Setiap dokter wajib melindungi makhluk insani;

5. Dalam melakukan pekerjaannya, seorang dokter harus mengutamakan

kepentingan masyarakat dan memperhatikan semua aspek pelayanan kesehatan yang menyeluruh, serta berusaha menjadi pendidik dan pengabdi masyarakat yang sebenarnya;

6. Setiap dokter wajib bersikap tulus ikhlas dan menggunakan segala ilmu dan keterampilannya untuk kepentingan penderita;

7. Setiap dokter wajib merahasiakan segala sesuatu yang diketahuinya tentang seorang penderita, bahkan setelah penderita meninggal dunia;

47 Alexandra Indriyanti Dewi, 2008. Etika dan Hukum Kesehatan, Pustaka Book Publisher, Yogyakarta, hal. 138-143
8. Setiap dokter wajib melakukan pertolongan darurat sebagai tugas kemanusiaan, kecuali bila ia yakin ada orang lain bersedia dan mampu memberikannya;

9. Setiap dokter tidak diperbolehkan mengambil alih penderita dari teman sejawatnya tanpa persetujuannya.

Kewajiban-kewajiban dokter terhadap pasien dalam melaksanakan pelayanan kesehatan sebagaimana diuraikan di atas, diatur lebih konkret dalam ketentuan Pasal 51 UU 29/2004 tentang Praktik Kedokteran.

Jumlah dokter di Indonesia saat ini cukup untuk mencukupi seluruh rakyat. Masalahnya, dokter-dokter itu berkumpul di sejumlah kota dan provinsi tertentu. Dokter enggan ditempatkan di daerah pedalaman karena kurangnya peralatan kesehatan. Data dari konsil Kedokteran Indonesia (KKI) menyebutkan bahwa jumlah dokter umum yang telah teregistrasi oleh KKI sampai dengan februari 2015 berjumlah 103.537 orang. Data dari Dirjen Dikti Kementrian Pendidikan dan Kebudayaan tahun 2010 rasio dokter umum per 100.000 pendududuk DKI Jakarta terdapat 134,5 dokter umum. Sedangkan jumlah dokter umum di papua sebanyak 15,53 per 100.000 penduduk. Sedangkan Menurut data Konsil Kedokteran Indonesia (KKI) per 9 Mei 2016, jumlah dokter 110.720 orang, artinya satu dokter melayani 2.270 
1027 | Jurnal Idea Hukum

Vol. 4 No. 2 Oktober 2018

Magister Hukum Fakultas Hukum Universitas Jenderal Soedirman

penduduk. Hal ini yang menyebabkan banyak masyarakat di daerah daerah terpencil sulit mendapatkan pelayanan kesehatan yang memadai. ${ }^{48}$ Usman Sumantri selaku Kepala Badan Pengembangan dan Pemberdayaan Sumber Daya Manusia Kesehatan Kementerian Kesehatan menyatakan bahwa, persoalan di Indonesia adalah bukan jumlah dokter kurang, tetapi sebaran tidak merata. Dari 9.731 puskesmas yang ada, 5 persen tak punya dokter sama sekali. Sementara 9 persen puskesmas lain memiliki dokter, tetapi tempat tinggal dokternya jauh dari puskesmas karena lokasi puskesmas terpencil. $^{49}$

Jumlah dokter yang sedikit di beberapa daerah menyebabkan seringnya dokter yang menyelenggarakan praktik mandiri atau dokter puskesmas mendelegasikan atau melimpahkan kewenangan dalam melakukan praktik kedokteran kepada tenaga tenaga kesehatan yang memiliki kompetensi yang berbeda, seperti Bidan. Dalam rangkaian tindakan kedokteran tidak sepenuhnya dapat ditangani oleh dokter akan tetapi harus

${ }^{48}$ Lusia Kus Anna, Jumlah Dokter di Indonesia Cukup, tetapi Menumpuk di Kota Besar, http://health.kompas.com/read/2016/05/ 10/093908423/Jumlah.Dokter.di.Indones ia.Cukup.Tapi.Menumpuk.di.Kota.Besar, diakses pada tanggal 29 Oktober 2016 jam 11.00 WIB

${ }^{49} \mathrm{lbid}$. terlibat tenaga kesehatan lain yang dalam hal ini tenaga perawat. ${ }^{50}$ Pelayanan kesehatan dasar di Puskesmas tidak bisa sepenuhnya dilaksanakan oleh dokter, sehingga banyak pelayanan/tindakan medik yang merupakan kewenangan dokter dikerjakan oleh perawat/bidan, juga pelayanan medik di Puskesmas Keliling maupun Puskesmas Pembantu hanya dilayani oleh tenaga perawat/bidan. Secara yuridis, tenaga perawat/bidan tidak mempunyai kewenangan untuk melaksanakan pelayanan medik.

Pasal 73 Undang-undang Nomor 29 Tahun 2004 tentang Praktik Kedokteran mengamanatkan bahwa:

(1) Setiap orang dilarang menggunakan identitas berupa gelar atau bentuk lain yang menimbulkan kesan bagi masyarakat seolah-olah yang bersangkutan adalah dokter atau dokter gigi yang telah memiliki surat tanda registrasi dan/atau surat izin praktik.

(2) Setiap orang dilarang menggunakan alat, metode atau cara lain dalam memberikan pelayanan kepada masyarakat yang menimbulkan kesan seolah-olah yang bersangkutan adalah dokter atau dokter gigi yang telah memiliki surat tanda

${ }^{50}$ Djaelani, 2008, Pelimpahan Kewenangan Dalam Praktik Kedokteran Kepada Perawat, Bidan Secara Tertulis Dapat Mengeliminasi Tanggung Jawab Pidana \& Perdata, Jurnal Hukum Kesehatan juni 2008, Ed pertama, hal. 9 
registrasi dan/atau surat izin praktik.

(3) Ketentuan sebagaimana dimaksud pada ayat (1) dan ayat (2) tidak berlaku bagi tenaga kesehatan yang diberi kewenangan oleh peraturan perundangundangan.

Pasal 73 ayat (3) Undang-Undang Nomor 29 Tahun 2004 tentang Praktik Kedokteran memberi peluang bagi bidan untuk melakukan tindakan medik jika memenuhi ketentuan peraturan perundang-undangan. Permenkes Nomor 2052/Menkes/Per/X/2011 tentang Izin Praktik dan Pelaksanaan Praktik Kedokteran, dalam Pasal 23 Ayat (1) memuat ketentuan

Dokter atau dokter gigi dapat memberikan pelimpahan suatu tindakan kedokteran atau kedokteran gigi kepada perawat, bidan atau tenaga kesehatan tertentu lainnya secara tertulis dalam melaksanakan tindakan kedokteran atau kedokteran gigi.

Dokter atau dokter gigi dapat memberikan pelimpahan suatu tindakan kedokteran atau kedokteran gigi kepada perawat, bidan atau tenaga kesehatan tertentu lainnya secara tertulis dalam melaksanakan tindakan kedokteran atau kedokteran gigi. Petunjuk teknis pelimpahan yang dimaksud Pasal 23 Ayat (1) ternyata belum diatur, padahal banyak pasien yang membutuhkan penanganan gawat darurat Obstetri dan Ginekologi yang bergantung pada dokter.
Kasus gawat darurat obstetri adalah kasus obstetri yang apabila tidak segera ditangani akan berakibat kematian ibu dan janinnya. Kasus ini menjadi penyebab utama kematian ibu janin dan bayi baru lahir. $^{51} \quad$ Sedangkan

Kegawatdaruratan neonatal ada lah situasi yang membutuhkan evaluasi dan manajemen yang tepat pada bayi baru lahir yang sakit kritis ( $\leq$ usia 28 hari) membutuhkan pengetahuan yang dalam mengenali perubahan psikologis dan kondisi patologis yang mengancam jiwa yang bisa saja timbul sewaktu-waktu. ${ }^{52}$ Pada kasus tersebut memerlukan tindakan yang cermat, tepat dan cepat. Pendelegasian kewenangan dokter umum kepada bidan dalam pelayanan obstetri dan neonatal emergensi dasar tentunya menjadi suatu permasalahan, yakni disatu sisi keterbatasan dokter di daerah menyebabkan tidak semua pasien dapat ditangani oleh dokter apalagi dalam keadaan darurat, sedangkan disisi lain hukum tidak memberikan aturan yang jelas dan tentunya ada implikasi hukum apabila terjadi permasalahan di belakang hari khususnya mengenai tanggungjawab.

\section{B. Rumusan Masalah}

${ }^{51}$ Abdul Saifuddin, 2002, Buku Panduan Praktis Pelayanan Kesehatan Maternal Dan Neonatal'. Yayasan Bina Pustaka Sarwono Prawirohardjo, Jakarta,hal. 67

${ }^{52}$ Tonia Brousseau,and Ghazala Q. Sharieff, MD. 2006. Newborn Emergencies: The First, 30Days of Life, Pediatr Clin North Am, hal, 106. 
1029 | Jurnal Idea Hukum

Vol. 4 No. 2 Oktober 2018

Magister Hukum Fakultas Hukum Universitas Jenderal Soedirman

Berdasarkan latar belakang tersebut di atas maka dapat diambil suatu rumusan masalah sebagai berikut:

1

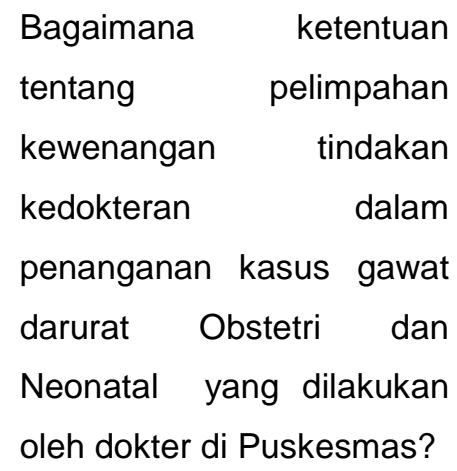

2. Bagaimana implikasi hukum bagi Bidan yang telah menjalankan praktik kedokteran Pelayanan Obstetri dan Neonatal Emergrnsi Dasar karena pelimpahan kewenangan tersebut?

\section{Metode Penelitian}

Metode Pendekatan yang digunakan Yuridis Normatif, dengan tipe Penelitian Preskripsi. Sumber Data yang dipakai adalah: Data Primer dan Data Sekunder. Metode Pengumpulan Data dilakukan dengan studi kepustakaan, Hasil penelitian selanjutnya dianalisis secara Normatif Kualitatif.

\section{Hasil Penelitian dan \\ Pembahasan}

I. Ketentuan Tentang Pelimpahan Kewenangan Tindakan Kedokteran Dalam Penanganan Kasus Gawat Darurat Obstetri Dan Neonatal yang dilakukan oleh dokter di

\section{Puskesmas}

Pembahasan mengenai ketentuan hukum ini akan penulis awali dengan analisis beberapa aspek hukum yang berlaku saat ini tentang:

1. Keterkaitan tugas Perawat, bidan, Dokter di Puskesmas, dan pelimpahan kewenangan Dokter kepada non Medis.

Tujuan nasional sebagaimana tercantum dalam pembukaan UUD 1945 adalah melindungi segenap bangsa Indonesia dan seluruh tumpah darah Indonesia dan memajukan kesejahteraan umum, mencerdaskan kehidupan bangsa dan ikut melaksanakan ketertiban dunia yang berdasarkan kemerdekaan perdamaian abadi serta keadilan sosial. Untuk mencapai tujuan nasional tersebut diselenggarakanlah upaya pembangunan yang berkesinambungan yang merupakan suatu rangkaian pembangunan yang menyeluruh terarah dan terpadu, termasuk di 


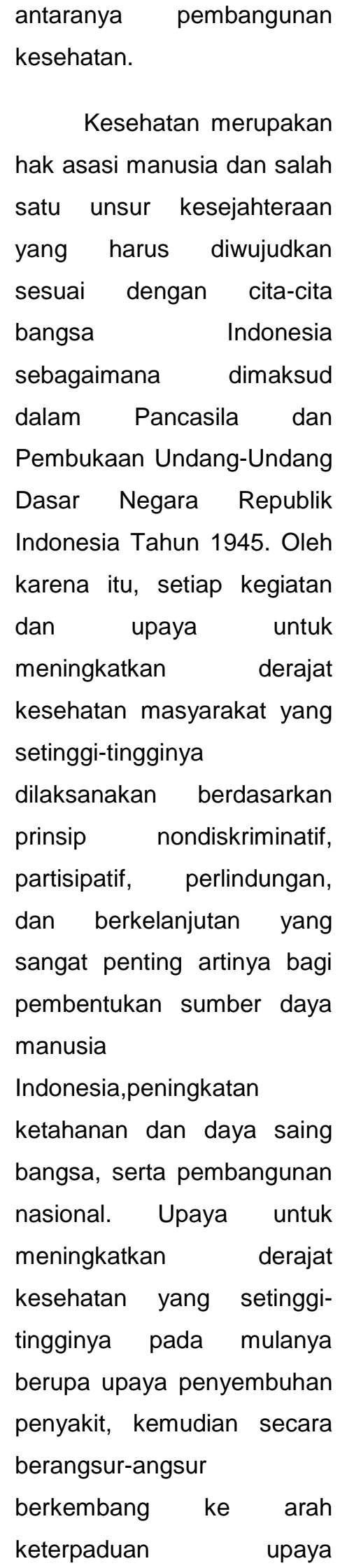

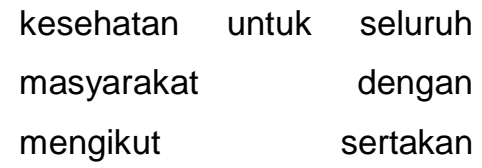

masyarakat secara luas yang mencakup upaya promotif, preventif, kuratif, dan rehabilitatif yang bersifat menyeluruh terpadu dan berkesinambungan.

Perkembangan ini tertuang ke dalam Sistem Kesehatan Nasional (SKN) pada tahun1982 yang selanjutnya disebutkan kedalam GBHN 1983 dan GBHN 1988 sebagai tatanan untuk melaksanakan pembangunan kesehatan.

\section{Penyelenggaraan}

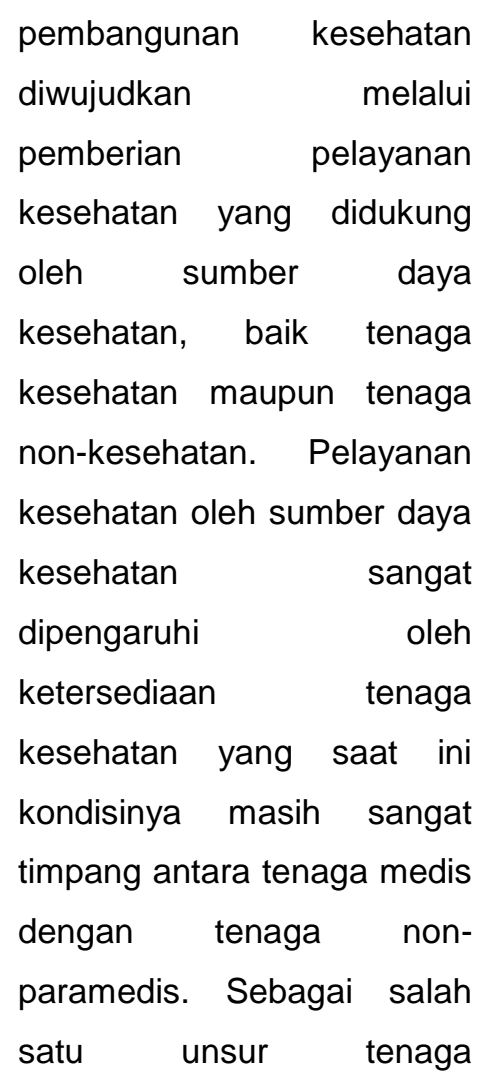


Vol. 4 No. 2 Oktober 2018

Magister Hukum Fakultas Hukum Universitas Jenderal Soedirman

kesehatan, perawat dan bidan memiliki peran penting terkait langsung dengan mutu pelayanan kesehatan sesuai dengan kompetensi dan pendidikan yang dimilikinya. Perawat sebagai tenaga keperawatan merupakan tenaga

kesehatan terbesar di Indonesia dengan jumlah $60 \%$ dari seluruh tenaga kesehatan yang ada.

\section{Puskesmas}

Gandrungmangu I Cilacap yang berlokasi di Jl. Raya Gandrungmanis-

Gandrungmangu No.1, Cilacap, Jawa Tengah, Indonesia. Puskesmas Gandrungmangu I melayani pasien rawat jalan, persalinan dan rawat inap. Puskesmas Gandrungmangu I merupakan Puskesmas yang cukup padat setiap hari senin pasien yang datang diatas 150 hingga 200, dengan keadaan puskesmas yang masih sempit dan kurangnya tenaga kesehatan.

Kondisi sumber daya manusia di Puskesmas Gandrungmangu I Cilacap antara lain sebagai berikut:
Tabel 4.1 Jumlah Sumber Daya Manusia Di Puskesmas Gandrungmangu I Cilacap

\begin{tabular}{|c|c|c|c|c|c|c|c|}
\hline \multirow[b]{2}{*}{ NO } & \multirow[b]{2}{*}{$\begin{array}{c}\text { JENIS } \\
\text { TENAG } \\
\text { A }\end{array}$} & \multicolumn{4}{|c|}{ STATUS } & \multirow[b]{2}{*}{$\mathrm{Jml}$} & \multirow[b]{2}{*}{ KET } \\
\hline & & $\begin{array}{l}\text { P } \\
N \\
S\end{array}$ & $\begin{array}{c}\text { PT } \\
\text { T }\end{array}$ & $\begin{array}{l}\text { HONO } \\
\text { R }\end{array}$ & $\begin{array}{c}\text { MAGAN } \\
\text { G }\end{array}$ & & \\
\hline 1. & Dokter & 2 & & & & 2 & \\
\hline 2. & $\begin{array}{l}\text { Umum } \\
\text { Dokter }\end{array}$ & 1 & & & & 1 & \\
\hline 3. & Gigi & 9 & & 9 & 5 & 20 & \\
\hline 4. & $\begin{array}{l}\text { Perawat } \\
\text { Umum }\end{array}$ & 1 & & & & 1 & \\
\hline 5. & $\begin{array}{l}\text { Perawat } \\
\text { Gigi }\end{array}$ & $\begin{array}{l}6 \\
5\end{array}$ & 11 & 1 & 1 & 8 & \\
\hline 7. & $\begin{array}{l}\text { Bidan } \\
\text { Puskesm } \\
\text { as }\end{array}$ & $\begin{array}{l}1 \\
2\end{array}$ & & & & $\begin{array}{c}16 \\
1\end{array}$ & \\
\hline 9. & $\begin{array}{l}\text { Bidan } \\
\text { Desa }\end{array}$ & 0 & & & & 2 & \\
\hline $\begin{array}{l}10 . \\
11 .\end{array}$ & $\begin{array}{l}\text { Sanitaria } \\
\mathrm{n}\end{array}$ & $\begin{array}{l}1 \\
5\end{array}$ & & & & $\begin{array}{l}0 \\
1\end{array}$ & \\
\hline 12. & Kesmas & 1 & & 1 & & 5 & \\
\hline 13. & Nutrisioni & & & 1 & & 2 & \\
\hline 14. & & & & 1 & 1 & 2 & \\
\hline & $\begin{array}{l}\text { Tata } \\
\text { Usaha }\end{array}$ & & & & 1 & 2 & \\
\hline & $\begin{array}{l}\text { Analis } \\
\text { Obat } \\
\text { AA }\end{array}$ & & & & & & \\
\hline & $\begin{array}{l}\text { Pengem } \\
\text { udi }\end{array}$ & & & & & & \\
\hline & $\begin{array}{l}\text { Kebersih } \\
\text { an }\end{array}$ & & & & & & \\
\hline
\end{tabular}




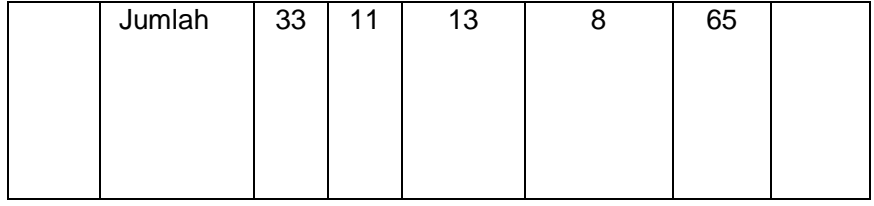

Sumber: Dokumen Puskesmas

Gandrungmangu I Cilacap 2017

Sumber daya manusia ini tentunya sangat berbanding terbalik dengan banyaknya masyarakat yang harus dilayani, antara lain:

Tabel 4.2 Jumlah Penduduk Gandrungmangu Cilacap

\begin{tabular}{|c|c|c|c|c|c|}
\hline \multirow[t]{2}{*}{$\mathbf{N}$} & \multirow[t]{2}{*}{ DESA } & \multicolumn{3}{|c|}{ JUMLAH PENDUDUK } & \multirow{2}{*}{$\begin{array}{c}\text { JML } \\
\text { KK } \\
\text { MISKIN }\end{array}$} \\
\hline & & $\mathbf{L}$ & $\mathbf{P}$ & JML & \\
\hline 1. & Cisumur & 4.666 & 4.859 & 9.759 & 2.933 \\
\hline 2. & Sidaurip & 3.803 & 3.902 & 7.705 & 2.271 \\
\hline 3. & Gintungreja & 3.738 & 3.402 & 7.140 & 1.891 \\
\hline 4. & Layansari & 4.560 & 4.648 & 9.208 & 3.929 \\
\hline 5. & $\begin{array}{l}\text { Gandrungm } \\
\text { anis }\end{array}$ & 4.029 & 4.220 & 8.249 & 2.702 \\
\hline 6. & Rulucori & 3.585 & 3.468 & 7.053 & 2.335 \\
\hline 7. & Gandrunam & 4.810 & 4.788 & 9.598 & 2.297 \\
\hline 8. & $\begin{array}{l}\text { angu } \\
\text { Muktisari }\end{array}$ & 3.427 & 3.503 & 6.930 & 2.639 \\
\hline & JUMLAH & 32.852 & 32.790 & 5.642 & 20.997 \\
\hline
\end{tabular}

Sumber: Dokumen Puskesmas

Gandrungmangu I Cilacap 2017

Perbandingan yang tidak seimbang tersebut diperparah dengan jarak rujukan yang cukup jauh sebagai berikut:
Tabel 4.3 Jumlah dan Jarak Rumah Sakit di Cilacap

\begin{tabular}{|l|l|l|}
\hline No & \multicolumn{1}{|c|}{ RS Rujukan } & \multicolumn{1}{c|}{ Jarak } \\
\hline 1. & RS Majenang & $45 \mathrm{Km}$ \\
2. & RSU Cilacap & $48 \mathrm{Km}$ \\
3. & RSUD Margono & $80 \mathrm{Km}$ \\
4. & RSU Banyumas & $80 \mathrm{Km}$ \\
5. & RSJ Magelang & $221 \mathrm{Km}$ \\
\hline
\end{tabular}

Sumber: Dokumen Puskesmas Gandrungmangu I Cilacap 2017

Keterbatasan tenaga medis (dokter) menimbulkan situasi yang mengharuskan perawat atau bidan melakukan tindakan pengobatan atau melakukan tindakan medis yang bukan wewenangnya. Tindakan tersebut dilakukan dengan atau tanpa adanya pelimpahan wewenang dari tenaga kesehatan lain termasuk dokter, sehingga dapat menimbulkan permasalahan hukum terkait dengan tanggung jawab yang dibebankan sepihak dan bisa merugikan perawat atau bidan. Hal ini berarti bahwa pelayanan kesehatan oleh tenaga kesehatan mengenal adanya pelimpahan wewenang, yang 
1033 | Jurnal Idea Hukum

Vol. 4 No. 2 Oktober 2018

Magister Hukum Fakultas Hukum Universitas Jenderal Soedirman

\begin{abstract}
biasa dikenal dengan
delegasi wewenang. Praktik

pelimpahan wewenang

(delegasi wewenang)

tersebut melibatkan

komunitas perawat atau

bidan, yang terjadi baik pada

pelayanan keperawatan

maupun praktik pelayanan

kesehatan. Delegasi

wewenang tersebut dipahami

sebagai pelimpahan dari

dokter kepada perawat atau

bidan untuk melaksanakan

tugas medis tertentu.
\end{abstract}

Belum tersedianya
petunjuk atau peraturan
mengenai jenis-jenis
tindakan medis tertentu yang
dapat dilakukan oleh perawat
atau bidan menyebabkan
seringnya terjadi tumpang
tindih antara tugas asuhan
keperawatan dengan tugas
yang merupakan pelimpahan
wewenang dari dokter. Cara
pelimpahan wewenang tugas
dokter kepada perawat atau
bidan dalam tindakan medis
di ruang rawat inap selama
ini dilakukan secara tertulis
dan secara lisan melalui
telepon. Pihak yang ikut
bertanggung jawab dalam
proses
wewenang adalah

Puskesmas, dan dokter

selaku pihak yang

memberikan pelimpahan

wewenang dan perawat dan

bidan selaku pelaksana yang

dilimpahi wewenang.

$\begin{array}{crr}\text { P } & \text { Nicolai } & \text { dalam } \\ \text { Juniarso } & \text { Ridwan } & \text { dan } \\ \text { Achmad } & \text { Sodik } & \text { Sudrajat } \\ \text { menyatakan } & \text { bahwa }\end{array}$

wewenang adalah :

Kemampuan untuk melakukan tindakan hukum tertentu (yaitu tindakan-tindakan yang dimaksudkan untuk menimbulkan akibat hukum, dan mencakup rnengenai timbul dan lenyapnya akibat hukum). Hak berisi kebebasan untuk melakukan atau tidak melakukan tindakan tertentu atau menurut pihak lainuntuk melakukan tindakan tertentu, sedangkan kewajiban memuat keharusan untuk melakukan atau tidak melakukan tindakan tertentu. $^{53}$

2. Pelimpahan Kewenangan Dokter kepada Perawat atau Bidan sebagai solusi untuk mengatasi kekurangan Dokter di Puskesmas Pelayanan Obstetri dan Emergensi Dasar

53 Juniarso Ridwan dan Achmad Sodik Sudrajat, Op cit., hal. 136. 
Pelimpahan

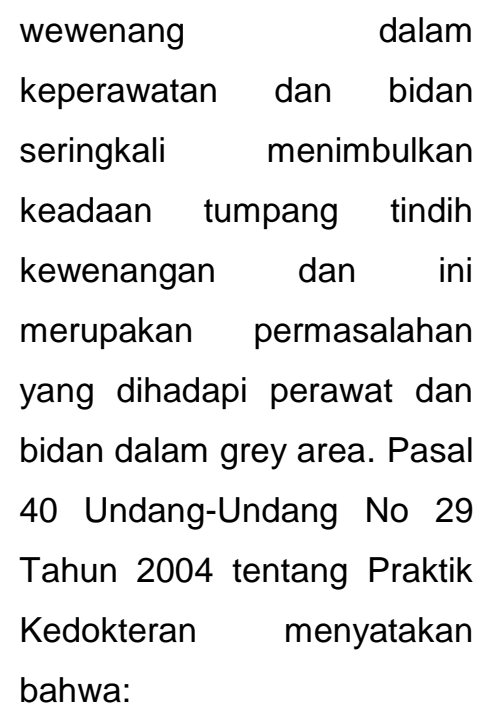

(1) Dokter atau dokter gigi yang berhalangan menyelenggarakan praktik kedokteran harus membuat pemberitahuan atau menunjuk dokter atau dokter gigi pengganti.

(2) Dokter atau dokter gigi pengganti sebagaimana dimaksud pada ayat (1) harus dokter atau dokter gigi yang mempunyai surat izin praktik.

\section{Pasal tersebut}

memberikan arahan bahwa,

pelimpahan wewenang

pengganti pada dasarnya

diarahkan kepada dokter

atau dokter gigi pengganti

bahkan, dokter atau dokter

gigi pengganti yang

mempunyai surat izin praktik.

Bagaimana dengan profesi

lainnya, baik perawat ataupun bidan, maka

penjelasan Pasal 40 ayat (2) menyatakan bahwa, dalam hal dokter atau dokter gigi pengganti bukan dari keahlian yang sama, dokter atau dokter gigi tersebut harus menginformasikan kepada pasien yang bersangkutan.

Sebagai pelaksanaan Pasal 38 Ayat (3) dan Pasal 43 Undang-Undang Nomor 29 Tahun 2004 tentang Praktik Kedokteran, telah diatur penyelenggaraan praktik dokter dan dokter gigi dengan Peraturan Menteri Kesehatan Nomor 1419/ Menkes / Per/X/2005 Kementerian Kesehatan mengeluarkan Peraturan Menteri Kesehatan Republik Indonesia Nomor 512/MENKES/PER/IV/2007

Tentang Izin Praktik Dan Pelaksanaan Praktik Kedokteran. Setelah peraturan tersebut dikeluarkan, pengaturan mengenai pelimpahan wewenang dokter lebih gamblang diatur.

Pasal 15 Peraturan Menteri Kesehatan Republik Indonesia Nomor 
1035 | Jurnal Idea Hukum

Vol. 4 No. 2 Oktober 2018

Magister Hukum Fakultas Hukum Universitas Jenderal Soedirman

512/MENKES/PER/IV/2007

Tentang Izin Praktik Dan

Pelaksanaan Praktik

Kedokteran bahwa:

(1) Dokter dan dokter gigi dapat memberikan pelimpahan suatu tindakan kedokteran atau kedokteran gigi kepada perawat, bidan atau tenaga kesehatan tertentu lainnya secara tertulis dalam melaksanakan tindakan kedokteran atau kedokteran gigi.

(2) Tindakan kedokteran atau kedokteran gigi sebagaimana dimaksud pada ayat (1) harus sesuai dengan kemampuan dan kompetensi yang dimiliki dan dilaksanakan sesuai ketentuan peraturan perundang-undangan.

(3) Pelimpahan wewenang kepada perawat, bidan atau tenaga lainnya dalam keadaan tertentu dimana pelayanan kesehatan sangat dibutuhkan dan tidak terdapat dokter dan dokter gigi di tempat tersebut diatur lebih lanjut dengan Peraturan Menteri .

Pasal 15 Peraturan

Menteri Kesehatan Republik Indonesia Nomor 512/MENKES/PER/IV/2007

Tentang Izin Praktik Dan

Pelaksanaan Praktik

Kedokteran memberikan kewenangan kepada dokter dan dokter gigi agar dapat memberikan pelimpahan suatu tindakan kedokteran atau kedokteran gigi kepada perawat, bidan atau tenaga kesehatan tertentu lainnya secara tertulis dalam melaksanakan tindakan kedokteran atau kedokteran gigi. Namun demikian Peraturan Menteri Kesehatan Republik Indonesia Nomor 512/MENKES/PER/IV/2007

Tentang Izin Praktik Dan

Pelaksanaan Praktik

Kedokteran juga tidak memberikan ketentuan yang detail mengenai proses pelimpahan kewenangan yang dimaksud, baik batasannya maupun prosedurnya.

Setelah empat tahun berlalu untuk memenuhi perkembangan dan kebutuhan hukum, serta revisi terhadap Peraturan Menteri Kesehatan Nomor 512/Menkes/Per/IV/2007 maka diundangkan Peraturan Menteri Kesehatan Nomor.

2052/MENKES/PER/X/2011 tentang Izin Praktik Dan Pelaksanaan Praktik 
Kedokteran. Pasal 23

Peraturan Menteri Kesehatan

Nomor.

2052/MENKES/PER/X/2011

tentang Izin Praktik Dan

Pelaksanaan Praktik

Kedokteran :

(1) dokter dan dokter gigi dapat memberikan pelimpahan suatu tindakan kedokteran atau kedokteran gigi kepada perawat, bidan atau tenaga tertentu lainnya secara tertulis dalam melaksanakan tindakan kedokteran atau kedokteran gigi"

(2) tindakan kedokteran atau kedokteran gigi sebagaimana

dimaksud pada ayat (1) hanya dapat dilakukan dalam keadaan dimana terdapat kebutuhan pelayanan yang melebihi ketersediaan dokter atau dokter gigi di fasilitas pelayanan tersebut".

(3) pelimpahan tindakan sebagaimana yang dimaksud pada ayat (1) dilakukan dengan ketentuan huruf":

a. Tindakan yang dilimpahkan termasuk dalam kemampuan dan keterampilan yang telah dimiliki oleh penerima pelimpahan;

b. pelaksanaan tindakan yang dilimpahkan tetap dibawah pengawasan pemberi pelimpahan; c. pemberi

pelimpahan tetap bertanggung jawab atas tindakan yang dilimpahkan

sepanjang pelaksanaan tindakan sesuai dengan pelimpahan yang diberikan;

d. tindakan yang dilimpahkan tidak termasuk mengambil

keputusan klinis sebagai dasar pelaksanaan tindakan;

e. tindakan yang dilimpahkan tidak terus menerus."

Pasal 23 Peraturan Menteri Kesehatan Nomor. 2052/MENKES/PER/X/2011 tentang Izin Praktik Dan Pelaksanaan Praktik Kedokteran memberikan pengaturan yang cukup jelas, bahwa dokter dan dokter gigi dapat memberikan pelimpahan suatu tindakan kedokteran atau kedokteran gigi kepada perawat, bidan atau tenaga tertentu lainnya secara tertulis dalam melaksanakan tindakan kedokteran atau kedokteran gigi. Pola tertulis dalam pelaksanaan pelimpahan wewenang dalam hal ini masih dipertahankan.

Selain itu alasan hanya dapat dilakukan dalam 
1037 | Jurnal Idea Hukum

Vol. 4 No. 2 Oktober 2018

Magister Hukum Fakultas Hukum Universitas Jenderal Soedirman

\begin{abstract}
keadaan dimana terdapat
kebutuhan pelayanan yang

melebihi ketersediaan dokter

atau dokter gigi di fasilitas

pelayanan tersebut juga

masih dipertahankan, dalam

arti pelimpahan wewenang

dari dokter kepada perawat,

bidan atau tenaga tertentu

lainnya diperbolehkan

dengan syarat khusus yaitu

keterbatasan dokter di

daerah tertentu/fasilitas

kesehatan tertentu.

Pelimpahan tindakan

yang diatur dalam Pasal 23

Peraturan Menteri Kesehatan

Nomor.

2052/MENKES/PER/X/2011

tentang Izin Praktik Dan

Pelaksanaan Praktik

Kedokteran juga telah

memiliki spesifikasi tertentu,

yaitu:
\end{abstract}

a. Tindakan yang dilimpahkan termasuk dalam kemampuan dan keterampilan yang telah dimiliki oleh penerima pelimpahan;

b. pelaksanaan tindakan yang dilimpahkan tetap dibawah pengawasan pemberi pelimpahan;

c. pemberi pelimpahan tetap bertanggung jawab atas tindakan yang dilimpahkan sepanjang pelaksanaan tindakan

$\begin{array}{lr}\text { sesuai } & \text { dengan } \\ \text { pelimpahan } & \text { yang } \\ \text { diberikan; } & \end{array}$

d. tindakan yang dilimpahkan tidak termasuk mengambil keputusan klinis sebagai dasar pelaksanaan tindakan;

e. tindakan yang dilimpahkan tidak terus menerus."

Pasal tersebut tidak menyatakan jenis pelimpahan wewenangnya, namun memberikan ciri-ciri dari tindakan yang harus dilakukan sorang penerima amanat seperti tindakan yang dilimpahkan tidak termasuk mengambil keputusan klinis sebagai dasar pelaksanaan tindakan dan tindakan yang dilimpahkan tidak terus menerus. Hal ini juga dipertegas dengan Pasal 27 Peraturan Menteri Kesehatan Republik Indonesia Nomor 28 Tahun 2017 tentang Izin Dan Penyelenggaraan Praktik Bidan.

Menurut Bagir Manan, wewenang dalam bahasa hukum tidak sama dengan kekuasaan (macht). Kekuasaan hanya menggambarkan hak untuk berbuat atau tidak berbuat. Dalam hukum, wewenang 


$$
\begin{aligned}
& \text { sekaligus berarti hak dan } \\
& \text { kewajiban (rechten en } \\
& \text { plichten). }{ }^{54} \text { Secara teoritis, } \\
& \text { terdapat tiga cara } \\
& \text { memperoleh kewenangan } \\
& \text { yang bersumber dari } \\
& \text { peraturan perundang- } \\
& \text { undangan yaitu: 1) } \\
& \text { pelimpahan kewenangan } \\
& \text { dengan atribusi; 2) } \\
& \text { pelimpahan kewenangan } \\
& \text { dengan delegasi, dan 3) } \\
& \text { pelimpahan kewenangan } \\
& \text { dengan mandat. }{ }^{55}
\end{aligned}
$$

Berdasarkan

perspektif administrasi, pelimpahan yang diatur dalam Pasal 23 Peraturan Menteri Kesehatan Nomor. 2052/MENKES/PER/X/2011 tentang Izin Praktik Dan Pelaksanaan Praktik Kedokteran bukan merupakan kewenangan atribusi. Dalam istilah hukum, atribusi diterjemahkan sebagai "pembagian (kekuasaan); dalam kata atributie van rechtsmacht; pembagian kekuasaan kepada berbagai instansi (kompetensi

${ }^{54}$ Ibid., hal. 137.

${ }^{55}$ Agussalim Andi Gadjong, 2007, Pemerintahan Daerah (kajian politik dan hukum), Ghalia Indonesia, Bogor, hal. 101 mutlak), sebagai lawan dari distributie van rechtmacht". Salah satu kekuasaan yang diberikan oleh UU kepada pemerintah adalah atribusi. Mengenai pengertian atribusi Indroharto mengemukakan bahwa yang dimaksud dengan atribusi adalah pemberian wewenang pemerintah yang baru oleh suatu ketentuan dalam perundang-undangan baik yang dilakukan oleh original legislator ataupun delegated legislator". ${ }^{56}$

Pasal 23 Peraturan Menteri Kesehatan Nomor. 2052/MENKES/PER/X/2011 tentang Izin Praktik Dan Pelaksanaan Praktik Kedokteran jelas-jelas tidak memberikan kewenangan baru terhadap bidan, perawat ataupun tenaga kesehatan lainnya. Selain itu kewenangan yang dilimpahkan melalui Pasal 23 Peraturan Menteri Kesehatan Nomor.

2052/MENKES/PER/X/2011 tentang Izin Praktik Dan Pelaksanaan Praktik Kedokteran bukan merupakan kewenangan

${ }^{56}$ Ibid., hal. 138 
1039 | Jurnal Idea Hukum

Vol. 4 No. 2 Oktober 2018

Magister Hukum Fakultas Hukum Universitas Jenderal Soedirman

yang tetap tetapi sementara

atau tindakan yang

dilimpahkan tidak terus

menerus.

3. Bentuk

Pelimpahan

Kewenangan

Dokter

kepada Perawat dan Bidan

di Puskesmas Pelayanan

Obstetri dan Neonatal

Emergensi Dasar

Membahas apakah

pelimpahan wewenang yang

diberikan dokter dalam hal ini

masuk dalam kategori

delegasi. Hal ini tentunya

perlu dikaji secara mendalam

baik spesifikasi delegasi dan

implikasi hukum delegasi

secara teoritik. Delegasi

adalah" penyerahan

wewenang dari pejabat yang

lebih tinggi kepada yang lebih

rendah. Penyerahan seperti ini

dianggap tidak bisa

dibenarkan selain dengan

atau berdasarkan kekuatan,

misalnya DPD kotapraja

memerintahkan kepada

majelis wali kota dan

pembantu wali kota untuk

mengadakan peraturan

tertentu.

HD. van Wijk dalam

buku Ridwan HR

berpendapat, bahwa

pengertian dari delegasi adalah "Penyerahan

wewenang pemerintah dari

suatu badan atau pejabat

pemerintahan kepada badan

atau pejabat pemerintahan

lain". Selanjutnya van Wijk menjelaskan lebih lanjut, bahwa wewenang yang di dapat dari pemberi delegasi didelegasikan lagi kepada subdelegetaris. Lebih lanjut lagi ia mengungkapkan:

Bentuk delegasi yang biasa adalah bentuk di mana dalam instansi pertama suatu wewenang pemerintahan yang dilambangkan kepada suatu lembaga pemerintahan diserahkan oleh lembaga ini kepada lembaga pemerintahan yang lainnya.Namun, pihak yang didelegasikan juga kadangkadang bisa menyerahkan wewenang ini, sehingga dapat berbicara tentang sub delegasi. Untuk sub delegasi berlaku mutatis, peraturan yang sama seperti untuk delegasi. $^{57}$

$$
\text { Pelimpahan }
$$

wewenang melalui delegasi tersebut terdapat syaratsyarat sebagai berikut:

a. Delegasi harus definitif dan pemberi delegasi tidak dapat lagi menggunakan sendiri wewenang yang telah dilimpahkan itu.

b. Delegasi harus berdasarkan ketentuan peraturan perundang-

${ }^{57}$ Ridwan HR, Op cit., hal. 103. 
$\begin{array}{lr}\text { undangan, artinya } \\ \text { delegasi } & \text { hanya } \\ \text { dimungkinkan } \quad \text { kalau } \\ \text { ada ketentuan untuk itu } \\ \text { dalam peraturan } \\ \text { perundang-undangan. }\end{array}$

c. Delegasi tidak kepada bawahan, artinya dalam hubungan hierarki kepegawaian tidak diperkenankan adanya delegasi.

d. Kewajiban memberikan keterangan (penjelasan), artinya delegasi berwenang untuk meminta penjelasan tentang pelaksanaan wewenang tersebut.

e. Peraturan kebijakan, artinya delegan memberikan instruksi (petunjuk) tentang penggunaan wewenang tersebut. ${ }^{58}$

Delegasi itu harus menggunakan dasar hukum karena jika seseorang yang memberikan atau mendelegasikan

wewenangnya kepada orang lain ingin mencabut kembali kewenangannya itu maka harus dengan peraturan yang sama. Menurut pendapatan ahli Heinrich Triepel yang dikutip oleh Agus Salim dalam bukunya yang berjudul Pemerintahan Daerah Kajian Politik dan Hukum menyatakan bahwa Sodik Sudrajat, Op cit., hal. 139 pendelegasian dalam pengertian hukum publik dimaksudkan tindakan hukum pemangku sesuatu wewenang kenegaraan. Jadi pendelegasian ini merupakan pergeseran kompetensi, pelepasan dan penerimaan sesuatu wewenang yang keduanya berdasarkan atas kehendak pihak yang menyerahkan kewenangan itu. Sehingga Pihak yang mendelegasikan itu haruslah mempunyai suatu wewenang yang sekarang tidak digunakannya sedangakan yang menerima pendelegasian juga biasanya mempunyai suatu wewenang sekarang akan memperluas apa yang telah diserahkan. ${ }^{59}$ Delegasi dapat diartikan sebagai pelimpahan wewenang dan tanggung jawab formal kepada orang lain untuk melaksanakan kegiatan tertentu. Sedangkan delegasi wewenang adalah proses di mana para manajer mengalokasikan wewenang ke bawah kepada orangorang yang melapor kepadanya.

Pasal 23 Peraturan Menteri Kesehatan Nomor.

${ }^{59}$ Agus Salim, Op cit., hal.. 104 
1041 | Jurnal Idea Hukum

Vol. 4 No. 2 Oktober 2018

Magister Hukum Fakultas Hukum Universitas Jenderal Soedirman

\begin{abstract}
2052/MENKES/PER/X/2011
tentang Izin Praktik Dan

Pelaksanaan Praktik

Kedokteran memiliki

karakteristik delegasi namun

juga memiliki karakteristik

mandat. Pelimpahan

wewenang yang

berkarakteristik delegasi

yaitu dokter dan dokter gigi

dapat memberikan

pelimpahan suatu tindakan

kedokteran atau kedokteran

gigi kepada perawat, bidan

atau tenaga tertentu lainnya

secara tertulis dalam

melaksanakan tindakan

kedokteran atau kedokteran

gigi begitupula ketentuan

tersebut disandarkan atas

peraturan perundang-

undangan. Namun demikian

dari segi tanggungjawab

pemberi pelimpahan tetap

bertanggung jawab atas

tindakan yang dilimpahkan

sepanjang pelaksanaan

tindakan sesuai dengan

pelimpahan yang diberikan,

selain itu tindakan yang

dilimpahkan tidak termasuk

mengambil keputusan klinis

sebagai dasar pelaksanaan

tindakan, bahkan tindakan

yang dilimpahkan tidak terus

menerus hal ini
\end{abstract}

mencerminkan ciri mandat.
HD. van Wijk

menjelaskan arti mandat

adalah suatu organ

pemerintahan mengizinkan

kewenangannya dijalankan

oleh organ lain atas

namanya. Berbeda dengan

delegasi, mengenai mandat,

pemberi mandat tetap

berwenang untuk melakukan

sendiri wewenangnya

apabila ia menginginkan, dan

memberi petunjuk kepada

mandataris tentang apa yang

diinginkannya. Mandans atau

pemberi mandat tetap

bertanggung jawab atas

tindakan yang dilakukan oleh

mandataris sebagaimana

yang dikatakan oleh van

Wijk, sebagai berikut:

Pada mandat tidak dapat berbicara tentang pemindahan kekuasaan atau wewenang di dalam arti yuridis, sekarang telah ditangani oleh dan atas nama lembaga pemerintahan yang bersangkutan, penanganannya juga diserahkan kepada lembaga tersebut; berbicara secara yuridis, tetap merupakan keputusan lembaga itu sendiri. Di sini berbicara tentang suatu bentuk perwakilan lembaga pemerintahan. Pemberi mandat atau mandans juga tetap berwenang untuk menangani sendiri wewenang bila mana ia kehendaki, ia bisa memberikan kepada para mandatarisnya segala bentuk 
yang dianggapnya perlu, seluruhnya bertanggung jawab atas segala keputusan yang diambil berdasarkan mandat. Secara yuridis, perkataan mandataris tidak lain dari perkataan mandans. ${ }^{60}$

Berdasarkan pendapat van Wijk, mandat tidak berbicara tentang pemindahan kekuasaan atau wewenang di dalam arti yuridis, mandat merupakan suatu bentuk perwakilan lembaga pemerintahan. Pemberi mandat atau mandans juga tetap berwenang untuk menangani sendiri wewenang bila mana ia kehendaki, ia bisa memberikan kepada para mandatarisnya segala bentuk yang dianggapnya perlu. Secara yuridis, perkataan mandataris tidak lain dari perkataan Mandan. Walaupun hampir sama dengan delegasi, namun mandat bukanlah pelimpahan keseluruhan wewenang, namun hanya pelaksana wewenang.

Perbedaan delegasi dengan mandat dapat dilihat dalam matriks sebagai

berikut:

Tabel 4.4 Perbedaan Delegasi dan Mandat

\begin{tabular}{|l|l|l|}
\hline No. & \multicolumn{1}{|c|}{ Delegasi } & \multicolumn{1}{c|}{ Mandat } \\
\hline 1. & $\begin{array}{l}\text { Pelimpahan } \\
\text { wewenang }\end{array}$ & $\begin{array}{l}\text { Perintah untuk } \\
\text { melaksanakan }\end{array}$ \\
\hline 2. & $\begin{array}{l}\text { Kewenangan } \\
\text { tidak dapat } \\
\text { dijalankan secara } \\
\text { insidental oleh } \\
\text { organ yang } \\
\text { memiliki } \\
\text { wewenang asli }\end{array}$ & $\begin{array}{l}\text { Kewenangan } \\
\text { dapat pewaktu- } \\
\text { waktu dilakanakan } \\
\text { oleh } \\
\text { mandata } \\
\text { (mandans). }\end{array}$ \\
\hline 3. & $\begin{array}{l}\text { Terjadi peralihan } \\
\text { tanggung jawab }\end{array}$ & $\begin{array}{l}\text { Tidak terjadi } \\
\text { peralihan } \\
\text { tanggung jawab }\end{array}$ \\
\hline 4. & $\begin{array}{l}\text { Harus harus } \\
\text { berdasarkan UU }\end{array}$ & $\begin{array}{l}\text { Tidak } \\
\text { berdasarkan UU }\end{array}$ \\
\hline 5. & $\begin{array}{l}\text { Harus tertulis } \\
\text { Dapat } \\
\text { tertulis,dapat pula }\end{array}$ \\
\hline
\end{tabular}

Berdasarkan perbedaan tersebut, walaupun memiliki karakteristik delegasi, namun Pasal 23 Peraturan Menteri Kesehatan Nomor. 2052/MENKES/PER/X/2011 tentang Izin Praktik Dan Pelaksanaan Praktik Kedokteran dominan kearah mandat. Hal ini dapat tercermin dalam ciri perintah untuk melaksanakan, kewenangan dapat sewaktu-waktu dilakanakan oleh pemberi serta tidak terjadi peralihan tanggung jawab. Pelimpahan wewenang terjadi secara terbatas yaitu pelaksanaan tindakan yang dilimpahkan tetap dibawah pengawasan pemberi 
1043 | Jurnal Idea Hukum

Vol. 4 No. 2 Oktober 2018

Magister Hukum Fakultas Hukum Universitas Jenderal Soedirman

pelimpahan, pemberi pelimpahan tetap bertanggung jawab atas tindakan yang dilimpahkan sepanjang pelaksanaan tindakan sesuai dengan pelimpahan yang diberikan, tindakan yang dilimpahkan tidak termasuk mengambil keputusan klinis sebagai dasar pelaksanaan tindakan serta tindakan yang dilimpahkan tidak terus menerus atau sementara.

Hubungan dokter dan perawat dalam pemberian pelayanan kesehatan kepada pasien merupakan hubungan kemitraan yang lebih mengikat. Dalam hubungan tersebut harus terjadi harmonisasi tugas, peran, tanggung jawab dan sistem yang terbuka. Hubungan dokter dan perawat juga memiliki hubungan hukum, karena pelimpahan wewenang baik delegasi maupun mandat yang diberikan dokter kepada perawat. Secara yuridis tanggung jawab berada pada dokter karena yang dilakukan perawat adalah instruksi dari dokter.

Setelah tiga tahun lamanya sejak Peraturan Menteri Kesehatan Nomor. 2052/MENKES/PER/X/2011 tentang Izin Praktik Dan Pelaksanaan Praktik Kedokteran diundangkanlah UU 36/2014 Tentang Tenaga Kesehatan.

$\begin{array}{lrr}\text { Pasal } 65 & \text { ayat (1) UU } & \text { 36/2014 } \\ \text { Tentang } & \text { Tenaga } & \text { Kesehatan } \\ \text { menjelaskan } & \text { bahwa, } & \text { dalam }\end{array}$

melakukan pelayanan kesehatan, Tenaga Kesehatan dapat menerima pelimpahan tindakan medis dari tenaga medis. Pasal 65 ayat (2) UU 36/2014 Tentang Tenaga Kesehatan menyatakan bahwa, dalam melakukan pekerjaan kefarmasian, tenaga teknis kefarmasian dapat menerima pelimpahan pekerjaan kefarmasian dari tenaga apoteker.

Pasal 65 ayat (3) UU 36/2014

Tentang Tenaga Kesehatan menyatakan bahwa, pelimpahan tindakan sebagaimana dimaksud pada ayat (1) dan ayat (2) dilakukan dengan ketentuan:

a. tindakan yang dilimpahkan termasuk dalam kemampuan dan keterampilan yang telah dimiliki oleh penerima pelimpahan;

b. pelaksanaan tindakan yang dilimpahkan tetap di bawah pengawasan pemberi pelimpahan;

c. pemberi pelimpahan tetap bertanggung jawab atas tindakan yang dilimpahkan sepanjang pelaksanaan tindakan sesuai dengan pelimpahan yang diberikan; dan

d. tindakan yang dilimpahkan tidak termasuk pengambilan keputusan sebagai dasar pelaksanaan tindakan.

Perawat dalam menjalankan tugasnya dalam menerima wewenang sebagaimana yang dimaksud dalam UU Keperawatan hanya dapat diberikan secara tertulis oleh tenaga medis kepada perawat untuk melakukan sesuatu tindakan 
medis dan melakukan evaluasi pelaksanaannya. Wewenang yang diberikan terbagi menjadi dua yakni tugas yang diberikan secara delegasi dan atau yang diberikan secara mandat. Dalam Pasal 32 ayat (1) Undang-undang No. 38 tahun 2014 tentang Keperawatan menyatakan bahwa, pelaksanaan tugas berdasarkan pelimpahan wewenang sebagaimana dimaksud dalam Pasal 29 ayat (1) huruf e hanya dapat diberikan secara tertulis oleh tenaga medis kepada Perawat untuk melakukan sesuatu tindakan medis dan melakukan evaluasi pelaksanaannya. Pelimpahan wewenang tersebut dapat dilakukan secara delegatif atau mandat.

II. Implikasi Hukum Bagi Bidan yang Telah Menjalankan Praktik Kedokteran Karena Pelimpahan wewenang di Puskesmas Pelayanan Obstetri dan Emergensi Dasar.

Setelah diketahui ketentuan tentang pelimpahan kewenangan tindakan Kedokteran yang dilakukan oleh dokter di Puskesmas, sebagaimana penulis kemukakan di atas, berikut penulis sajikan analisis tentang bagaimana Implikasi hukum bagi bidan yang telah menjalankan praktik Kedokteran karena pendelegasian wewenang tersebut.
1. Dasar Hukum Kewenangan Bidan dalam Menjalankan Tugasnya.

Pembangunan

kesehatan ditujukan untuk meningkatkan kesadaran, kemauan dan kemampuan hidup sehat bagi setiap orang dalam rangka mewujudkan derajat kesehatan yang optimal sebagai salah satu unsur kesejahteraan sebagaimana dimaksud dalam Pembukaan Undang-Undang Dasar 1945. Kesehatan sebagai hak asasi manusia harus diwujudkan dalam bentuk pemberian berbagai upaya pelayanan kesehatan yang berkualitas dan terjangkau oleh masyarakat. Pelayanan keperawatan merupakan bagian integral dari pelayanan kesehatan ditujukan kepada individu, kelompok dan masyarakat yang memiliki masalah fisik, mental maupun sosial di berbagai tatanan pelayanan kesehatan.

Kesehatan sebagai hak asasi manusia merupakan tanggung jawab pemerintah dan seluruh elemen masyarakat, harus diwujudkan dalam bentuk pemberian berbagai upaya kesehatan 
1045 | Jurnal Idea Hukum

Vol. 4 No. 2 Oktober 2018

Magister Hukum Fakultas Hukum Universitas Jenderal Soedirman

melalui penyelenggaraan

pembangunan kesehatan yang

berkualitas. Pelaksanaan

pelayanan kesehatan di

lapangan, perawat, bidan atau

paramedis lain nya sering

mendapat pelimpahan tugas

dari dokter yang berupa

mandat (karena tanggung jawabnya tetap pada dokter). ${ }^{61}$

Diantaranya memberikan

pelayanan pengobatan

(kuratif) dan tindakan khusus

(yang menjadi wewenang

dokter dan seharusnya

dilakukan oleh dokter) seperti pemasangan infus, melakukan suntikan. Dalam hal itu setiap kegagalan dalam tindakan medis menjadi tanggung jawab dokter.

Sebagaimana telah di bahas di atas bahwa, pemberi mandat tetap berwenang untuk melakukan sendiri wewenangnya apabila ia menginginkan, dan memberi petunjuk kepada mandataris tentang apa yang diinginkannya. Mandans atau pemberi mandat tetap bertanggung jawab atas

${ }^{61}$ Anggraini Jum, 2012, Hukum Administrasi Negara, Graha IImu, Yogyakarta, Cetakan Pertama, hal.9192. tindakan yang dilakukan oleh mandataris. ${ }^{62}$ Artinya menjadi suatu kondisi yang benar bahwa perawat dan bidan yang diberikan mandat, tanggngjawabnya masih ada pada dokter selaku pemberi mandat. Namun demikian dengan lahirnya kewenangan yang dapat di delegasikan kepada perawat, maka menimbulkan implikasi hukum yang berbeda dengan mandat.

Dalam konsep delegasi, pelimpahan wewenang delegasi penyerahan wewenang pemerintah dari suatu badan atau pejabat pemerintahan kepada badan atau pejabat pemerintahan lain. Delegasi adalah suatu pelimpahan wewenang dan tanggung jawab formal kepada orang lain untuk melaksanakan kegiatan tertentu. Tanggung jawab yuridis tidak lagi berada pada pemberi delegasi, tetapi beralih pada penerima delegasi.

$$
\text { Pasal } 32 \text { ayat }
$$

Undang-undang No. 38 tahun 2014 tentang Keperawatan menyatakan bahwa,

${ }^{62}$ Agus Salim, Op cit., hal. 139- 
Pelimpahan wewenang secara

delegatif untuk melakukan

sesuatu tindakan medis

diberikan oleh tanaga medis

(dokter) kepada perawat

dengan disertai pelimpahan

tanggung jawab. Pelimpahan

wewenang secara delegatif

hanya dapat diberikan kepada

Perawat profesi atau Perawat vokasi terlatih yang memiliki kompetensi yang diperlukan sebagaimana Pasal 32 ayat (4) Undang-undang No. 38 tahun $2014 \quad$ tentang Keperawatan. Dalam penjelasan Pasal 32 ayat (4) UU No. 38 tahun 2014 dijelaskan bahwa tindakan medis yang dapat dilimpahkan secara delegatif, antra lain menyuntik, memasang infus, dan memberikan imunisasi dasar sesuai dengan program pemerintah. Berdasarkan Pasal tersebut maka dapat disimpulkan bahwa, ketika terjadi pelimpahan wewenang secara delegatif dari dokter kepada perawat maka akibatakibat yang terjadi baik malpraktik ataupun risiko medis terhadap tindakan menyuntik, memasang infus, dan memberikan imunisasi dasar menjadi tanggungjawab perawat.
Pasal $51 \quad$ Undang-

Undang Republik Indonesia Nomor 29 Tahun 2004 tentang Praktik

Kedokteran menyatakan bahwa, dokter atau dokter gigi dalam melaksanakan praktik kedokteran mempunyai kewajiban, diantaranya memberikan pelayanan medis sesuai dengan standar profesi dan standar prosedur operasional serta kebutuhan medis pasien. Kemudian pada Pasal 42 Undang-Undang Republik Indonesia Nomor 29/ 2004 juga dijelaskan bahwa pimpinan sarana pelayanan kesehatan dilarang mengizinkan dokter ataupun dokter gigi yang tidak memiliki surat izin praktik untuk melakukan praktik kedokteran di sarana pelayanan kesehatan tersebut. Sedangkan di Pasal 40 Undang-Undang yang sama dinyatakan dokter atau dokter gigi yang berhalangan menyelenggarakan praktik kedokteran harus membuat pemberitahuan atau menunjuk dokter atau dokter gigi pengganti. Dokter atau dokter gigi sebagaimana dimaksud 
1047 | Jurnal Idea Hukum

Vol. 4 No. 2 Oktober 2018

Magister Hukum Fakultas Hukum Universitas Jenderal Soedirman

harus yang mempunyai surat izin praktik. ${ }^{63}$

Dalam kajian sub bab pertama yang membahas mengenai pelimpahan wewenang mandat dan delegasi baik terhadap perawat, bidan ataupun tenaga medis lainnya, dapat diketahui bahwa pelimpahan wewenang pada awalnya belum diatur secara spesifik, bahkan menjadi pertentangan terhadap Undang-Undang 29 Tahun 2004 tentang Praktik Kedokteran mengenai larangan berperilaku sebagai dokter tanpa surat izin praktik dokter. Namun demikian Pasal 23 Peraturan Menteri Kesehatan Nomor. 2052/MENKES/PER/X/2011 tentang Izin Praktik Dan Pelaksanaan Praktik Kedokteran memberikan dasar hukum bagi pelaksanaan pelimpahan wewenang. Kemudian Pasal 32 Undangundang No. 38 tahun 2014 tentang Keperawatan yang memberikan dasar hukum terhadap perawat dalam

${ }^{63}$ Darda Syahrizal \& Nila Senjasari, Undang-Undang Praktik Kedokteran dan Aplikasinya, Dunia Cerdas, Jakarta, hal. 134-140. melaksanakan pelimpahan wewenang delegasi. Bagaimana dengan bidan, apakah dalam praktik bidan telah diatur pelimpahan wewenang yang demikian, dan bagaimana apabila ternyata telah terjadi pelimpahan wewenang delegasi.

Hingga saat ini (2017) bidan belum pernah diatur khusus dalam suatu UndangUndang seperti halnya dokter dan perawat. Namun demikian Bidan diatur dalam Peraturan Menteri Kesehatan Republik Indonesia Nomor 28 Tahun 2017 tentang Izin Dan Penyelenggaraan Praktik Bidan, Pasal 22, bidan memiliki kewenangan memberikan pelayanan berdasarkan:
a. penugasan dari pemerintah sesuai kebutuhan; dan/atau

b. pelimpahan wewenang melakukan tindakan pelayanan kesehatan secara mandat dari dokter.

Kewenangan bidan secara umum tercantum dalam Pasal 18 Peraturan Menteri Kesehatan Republik Indonesia Nomor 28 Tahun 2017 tentang 
Izin Dan Penyelenggaraan

Praktik Bidan Praktik. Dalam

hal penyelenggaraan Praktik

Kebidanan Bidan, bidan

berwenang untuk memberikan pelayanan yang meliputi:

a. pelayanan kesehatan ibu;

b. pelayanan kesehatan anak; dan

c. pelayanan kesehatan reproduksi perempuan dan keluarga berencana.

Pelayanan kesehatan ibu diberikan pada masa pra hamil, kehamilan, masa persalinan, masa nifas, masa menyusui dan masa antara dua kehamilan. Pelayanan kesehatan ibu pada masa pra hamil, kehamilan, masa persalinan, masa nifas, masa menyusui dan masa antara dua kehamilan meliputi:
a. pelayanan konseling pada masa sebelum hamil;
b. pelayanan antenatal pada kehamilan normal;
c. pelayanan persalinan normal;
d. pelayanan ibu nifas normal;
e. pelayanan ibu menyusui; dan
f. pelayanan konseling pada masa antara dua kehamilan.

Bidan sebagaimana

Pasal 19 Peraturan Menteri Kesehatan Republik Indonesia Nomor 28 Tahun 2017 tentang Izin Dan Penyelenggaraan Praktik Bidan dalam memberikan pelayanan tersebut berwenang untuk:

a. episiotomi;

b. pertolongan persalinan normal;

c. penjahitan luka jalan lahir tingkat I dan II;

d. penanganan kegawatdaruratan, dilanjutkan dengan perujukan;

e. pemberian tablet tambah darah pada ibu hamil;

f. pemberian vitamin $\mathrm{A}$ dosis tinggi pada ibu nifas;

g. fasilitasi/bimbingan inisiasi menyusu dini dan promosi air susu ibu eksklusif;

h. pemberian uterotonika pada manajemen aktif kala tiga dan postpartum;

i. penyuluhan dan konseling;

j. bimbingan pada

kelompok ibu hamil; dan

k. pemberian surat keterangan kehamilan dan kelahiran.

Pelayanan kesehatan anak sebagaimana dimaksud dalam Peraturan Menteri Kesehatan Republik Indonesia Nomor 28 Tahun 2017 tentang Izin Dan Penyelenggaraan Praktik Bidan Pasal 18 huruf b diberikan pada bayi baru lahir, 
1049 | Jurnal Idea Hukum

Vol. 4 No. 2 Oktober 2018

Magister Hukum Fakultas Hukum Universitas Jenderal Soedirman

bayi, anak balita, dan anak prasekolah. Bidan dalam hal memberikan pelayanan kesehatan anak sebagaimana dimaksud pada ayat (1), bidan berwenang melakukan:
a. pelayanan neonatal esensial;
b. penanganan
kegawatdaruratan, dilanjutkan dengan perujukan;
c. pemantauan tumbuh kembang bayi, anak balita, dan anak prasekolah; dan
d. konseling dan penyuluhan.

Pelayanan noenatal esensial sebagaimana dimaksud pada ayat (2) huruf a meliputi inisiasi menyusui dini, pemotongan dan perawatan tali pusat, pemberian suntikan Vit $\mathrm{K} 1$, pemberian imunisasi B0, pemeriksaan fisik bayi baru lahir, pemantauan tanda bahaya, pemberian tanda identitas diri, dan merujuk kasus yang tidak dapat ditangani dalam kondisi stabil dan tepat waktu ke Fasilitas Pelayanan Kesehatan yang lebih mampu.

\section{Penanganan}

kegawatdaruratan, dilanjutkan dengan perujukan sebagaimana dimaksud pada ayat (2) huruf b meliputi:

a. penanganan awal asfiksia bayi baru lahir melalui pembersihan jalan nafas, ventilasi tekanan positif, dan/atau kompresi jantung;

b. penanganan awal hipotermia pada bayi baru lahir dengan BBLR melalui penggunaan selimut atau fasilitasi dengan cara menghangatkan tubuh bayi dengan metode kangguru;

c. penanganan awal infeksi tali pusat dengan mengoleskan alkohol atau povidon iodine serta menjaga luka tali pusat tetap bersih dan kering; dan

d. membersihkan dan pemberian salep mata pada bayi baru lahir dengan infeksi gonore (GO).

2. Tanggung Jawab Bidan yang Telah Melaksanakan Pelimpahan Kewenangan dari Dokter di Puskesmas dalam Pelayanan Obstetri Neonatal Emergensi Dasar.

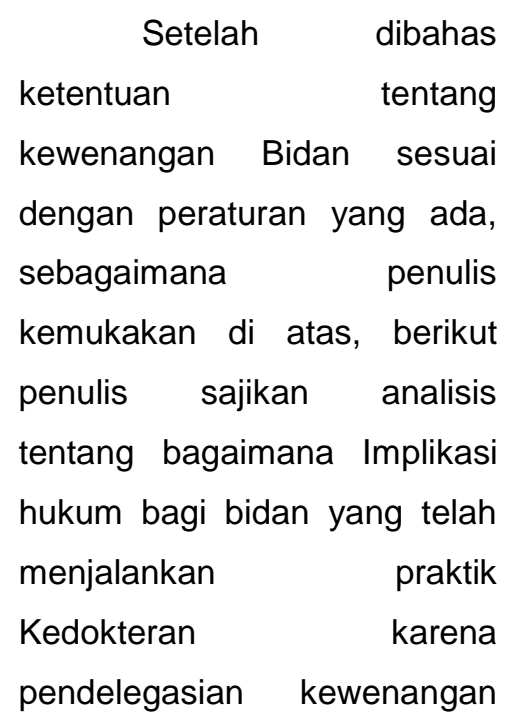


dalam Pelayanan Obstetri Emergensi Dasar.

a. Implikasi Hukum bagi Bidan yang Telah Melaksanakan

Pelimpahan

Kewenangan Dokter.

Dalam keadaan biasa dalam arti tidak dalam emergensi, berdasarkan Pasal 22 ayat (2) Peraturan Menteri Kesehatan Republik Indonesia Nomor 28 Tahun 2017 tentang Izin Dan Penyelenggaraan Praktik Bidan tentang Izin dan Penyelenggaran Praktik Bidan tidak bisa dijadikan dasar pelimpahan wewenang delegasi, justru Pasal 22 ayat (2) Peraturan Menteri Kesehatan Republik Indonesia Nomor 28 Tahun 2017 tentang Izin Dan Penyelenggaraan Praktik Bidan merupakan wewenang baru yang timbul oleh peraturan perundangundangan ketika terjadi kelangkaan dokter atau dapat disebut sebagai kewenangan atributif terbatas, karena juga memuat prasyarat pengguguran kewenangan yaitu ketika sudah ada dokter baru disuatu daerah. Oleh karena belum ada dasar hukum kewenangan delegasi secara jelas oleh dokter kepada bidan tindakan apa yang bisa didelegasikan.

\begin{tabular}{lrr}
\multicolumn{2}{r}{ Sebagaimana telah } \\
dibahas pada sub bab \\
sebelumnya Pasal 23
\end{tabular}

Peraturan Menteri Kesehatan Nomor.

2052/MENKES/PER/X/2011

tentang Izin Praktik Dan

Pelaksanaan Praktik

Kedokteran memberikan pengaturan yang cukup jelas, bahwa dokter dan dokter gigi dapat memberikan pelimpahan suatu tindakan kedokteran atau kedokteran gigi kepada perawat, bidan atau tenaga tertentu lainnya secara tertulis dalam melaksanakan tindakan kedokteran atau kedokteran gigi. Namun demikian tidak terjadi pelimpahan tanggungjawab disini, oleh karena itu sesuai Pasal 22 butir b Peraturan Menteri Kesehatan Republik Indonesia Nomor 28 Tahun 2017 tentang Izin Dan Penyelenggaraan Praktik Bidan tentang Izin dan Penyelenggaran Praktik Bidan jenis kewenangannya adalah kewenangan mandat.

Pasal 65 ayat (1) UU 36/2014 Tentang Tenaga Kesehatan menyatakan bahwa, dalam melakukan 
1051 | Jurnal Idea Hukum

Vol. 4 No. 2 Oktober 2018

Magister Hukum Fakultas Hukum Universitas Jenderal Soedirman

pelayanan kesehatan, Tenaga

Kesehatan dapat menerima

pelimpahan tindakan medis

dari tenaga medis. Kemudian

Pasal 65 ayat (3) UU 36/2014

Tentang Tenaga Kesehatan

menyatakan

bahwa,

pelimpahan

tindakan

sebagaimana dimaksud pada

ayat (1) dan ayat (2) dilakukan

dengan ketentuan:

a) tindakan yang dilimpahkan termasuk dalam kemampuan dan keterampilan yang telah dimiliki oleh penerima pelimpahan;

b) pelaksanaan tindakan yang dilimpahkan tetap di bawah pengawasan pemberi pelimpahan;

c) pemberi pelimpahan tetap bertanggung jawab atas tindakan yang dilimpahkan sepanjang pelaksanaan tindakan sesuai dengan pelimpahan yang diberikan; dan

d) tindakan yang dilimpahkan tidak termasuk pengambilan keputusan sebagai dasar pelaksanaan tindakan.

Pada Peraturan Menteri Kesehatan Republik Indonesia Nomor 46 Tahun 2015 tentang Akreditasi Puskesmas, Klinik Pratama, Tempat Praktik Mandiri Dokter, Dan Tempat Praktik Mandiri Dokter Gigi disebutkan Kriteria Penilaian
2.2.4. Dokter melakukan kajian awal untuk menetapkan diagnosis medis dan diagnosis keperawatan dengan Pokok Pikiran:

1) Kajian hanya boleh dilakukan oleh dokter yang kompeten sesuai dengan kebutuhan pasien. Kajian awal tersebut memberikan informasi untuk :

a) Memahami pelayanan apa yang dibutuhkan oleh pasien

b) Menetapkan diagnosis awal

c) Mengetahui riwayat pasien terhadap pengobatan sebelumnya

d) Memahami respon pasien terhadap pengobatan sebelumnya

e) Memilih jenis pelayanan/tindakan yang terbaik bagi pasien serta rencana tindak lanjut dan evaluasi

2) Pada keadaan tertentu, jika tenaga kesehatan professional yang kompeten tidak berada di tempat, maka proses kajian dapat didelegasikan kepada petugas kesehatan yang 
diberi kewenangan khusus

sesuai persyaratan pelatihan

yang ditetapkan oleh

pimpinan Praktik Mandiri.

3) Elemen Penilaian:

a) Kajian dilakukan oleh tenaga kesehatan yang profesional dan kompeten

b) Tersedia tim kesehatan antar profesi yang profesional untuk melakukan kajian jika diperlukan penanganan secara tim

c) Terdapat kejelasan proses pendelegasian wewenang secara tertulis kepada petugas yang diberi kewenangan, apabila pelayanan tidak dilakukan oleh tenaga kesehatan profesional yang memenuhi persyaratan

d) Petugas yang diberi kewenangan tersebut telah mengikuti pelatihan yang dipersyaratkan.

Berdasarkan ketentuan tersebut maka jenis pelimpahan kewenangannya bisa delegasi dan juga bisa mandat, hal ini dapat terlihat dari b dan d yaitu ketentuan pelaksanaan tindakan yang

dilimpahkan tetap di bawah

pengawasan pemberi

pelimpahan dan tindakan yang

dilimpahkan tidak termasuk pengambilan keputusan sebagai dasar pelaksanaan tindakan. Dalam mandat hanya sebagian wewenang yang dilimpahkan dan yang terpenting adalah tanggung jawab/pertanggungjawaban te tap pada sipemilik wewenang,sedangkan pada delegasi tanggung jawab ada pada dokter.

\section{E. Penutup}

\section{Simpulan}

Berdasarkan hasil penelitian dan pembahasan, maka dapat disimpulkan sebagai berikut:

1. Ketentuan tentang pelimpahan kewenangan tindakan kedokteran yang dilakukan oleh dokter di Puskesmas harus dilakukan secara tertulis, didasarkan atas Peraturan Menteri Kesehatan Nomor. 2052/MENKES/PER/X/2011 tentang Izin Praktik Dan Pelaksanaan Praktik Kedokteran dan Undang-undang No. 38 tahun 2014 tentang Keperawatan, tanggungjawab berada pada orang yang diberikan wewenang, kewenangan tidak dapat dicabut sewaktu-waktu, namun harus didasarkan atas pernyataan tertulis. Secara objektif delegasi khusus 
1053 | Jurnal Idea Hukum

Vol. 4 No. 2 Oktober 2018

Magister Hukum Fakultas Hukum Universitas Jenderal Soedirman

terhadap perawat diatur dalam Pasal 32 ayat (4) Undang-undang No. 38 tahun 2014 tentang Keperawatan yang menyatakan bahwa, pelimpahan wewenang delegatif tindakan medis yang dapat dilimpahkan secara delegatif, antara lain menyuntik, memasang infus, dan memberikan imunisasi dasar sesuai dengan program pemerintah dan atas tindakan tersebut menjadi tanggungjawab perawat dan pertanggungjawaban ada seluruhnya pada perawat. Secara subjektif berdasarkan, Pasal 32 ayat (4) Undang-undang No. 38 tahun 2014 tentang Keperawatan pelimpahan wewenang secara delegatif hanya dapat diberikan kepada Perawat profesi atau Perawat vokasi terlatih yang memiliki kompetensi yang diperlukan. Dokter selaku pemberi delegasi harus memperhatikan kompetensi perawat, sebagaimana diatur dalam Standar Kompetensi Perawat.

Sedangkan untuk bidan
pendelegasian diatur dalam Peraturan Menteri Kesehatan Republik Indonesia Nomor 28 Tahun 2017 tentang Izin Dan Penyelenggaraan Praktik Bidan tentang Izin dan Penyelenggaran Praktik Bidan, Peraturan Menteri Kesehatan Nomor. 2052/MENKES/PER/X/2011 tentang Izin Praktik Dan Pelaksanaan Praktik
Kedokteran dan UU 36/2014 Tentang Tenaga Kesehatan, dan Peraturan Menteri Kesehatan Republik Indonesia Nomor 46 Tahun 2015 tentang Akreditasi Puskesmas, Klinik Pratama, Tempat Praktik Mandiri Dokter, Dan Tempat Praktik Mandiri Dokter Gigi walaupun jenis tindakan yang bisa didelegasikan disebutkan secara jelas.

2. Implikasi Hukum Bagi Bidan yang telah menjalankan praktik kedokteran karena pelimpahan wewenang terbagi menjadi tiga implikasi yaitu etik dan administrasi, perdata dan pidana, antara lain sebagai berikut:

a. Implikasi Administrasi dan kode etik terhadap bidan yang telah menjalankan praktik kedokteran karena pendelegasian wewenang di Puskesmas PONED yaitu tidak dapat dikenakan tindakan administratif karena tidak melanggar kewenangan seorang bidan jika sudah ada pendelegasian secara tertulis, oleh karena itu tidak dapat dikenakan teguran lisan, teguran tertulis, pencabutan SIPB untuk sementara paling lama 1 (satu) tahun; atau pencabutan SIPB selamanya.

b. Secara perdata kewenangan yang dilimpahkan oleh dokter pada bidan melalui delegasi pada dasarnya adalah 
legal, sehingga ketika terjadi pelimpahan wewenang yang demikian, masuk pada kategori delegasi jika tanggungjawab pada Bidan dan bisa juga mandat dimana tanggungjawab tetap berada pada dokter selaku pemberi mandat dimana Bidan tidak hanya bertanggungjawab sendiri dalam hal ini, tetapi dokter selaku pemberi wewenang juga ikut bertanggungjawab sebagaimana diatur dalam Pasal 1367 KUHPerdata.

C. Secara pidana Bagi Bidan yang Telah Menjalankan Praktik Kedokteran Karena Pendelegasian wewenang dokter ketika terjadi malpraktik maka dapat dikenakan Pasal 84 UU 36/2014 Tentang Tenaga Kesehatan menyatakan bahwa setiap Tenaga Kesehatan yang melakukan kelalaian berat yang mengakibatkan

Penerima

Pelayanan Kesehatan luka berat dipidana dengan pidana penjara paling lama 3 (tiga) tahun. Apabila kelalaian kelalaian tersebut mengakibatkan kematian, setiap Tenaga Kesehatan dipidana dengan pidana penjara paling lama 5 (lima) tahun.

\section{Saran}

1. Sebaiknya dokter dan fasilitas kesehatan memahami ketentuan mengenai pendelegasian kewenangan

tindakan

kedokteran.

2. Sebaiknya tidak dilakukan pendelegasian wewenang dokter kepada bidan jika tidak dalam keadaan darurat, tetapi pelimpahan wewenang melalui mandat.

3. Perlu adanya UU praktik Bidan yang mengatur secara jelas tentang pendelegasian kewenangan Dokter kepada Bidan, yang bisa memberikan solusi terhadap keadaan tidak meratanya penyebaran dokter di Indonesia yang mengakibatkan masih banyaknya kekosongan dokter di Fasilitas Kesehatan.

\section{DAFTAR PUSTAKA}

Amir, Amri.1997. Bunga Rampai Hukum Kesehatan. Widya Medika. Jakarta.

Brousseau, Tonia and Ghazala Q. Sharieff. MD. 2006. Newborn Emergencies: The First. 30Days of Life.Pediatr Clin North Am.

Dewi, Alexandra Indriyanti. 2008. Etika dan Hukum Kesehatan. Pustaka Book Publisher. Yogyakarta.

Gadjong, Agussalim Andi. 2007. Pemerintahan Daerah (kajian politik dan hukum). Ghalia Indonesia. Bogor.

Hadjon, Philiphus M. dan Tatiek Sri Djatmiati. 2010. Argurmntasi Hukum. Gajah mada University Press. Yogyakarta.

Hartono, Sri Rejeki. 2000. Kapita Selekta Hukum Ekonomi. Mandar Maju. Bandung. 
1055 | Jurnal Idea Hukum

Vol. 4 No. 2 Oktober 2018

Magister Hukum Fakultas Hukum Universitas Jenderal Soedirman

HR, Ridwan. 2007. Hukum Administrasi Negara. PT.Raja Grafindo Persada. Jakarta.

2011. Hukum Administrasi Negara. EdisiRevisi.PT Raja Grafindo Persada. Jakarta.

Kansil, C.S.T. 2001. Pengantar IImu Hukum dan Pengantar Hukum Indonesia. Balai Pustaka. Jakarta.

Kerbala, Husein. 1997.Segi-segi Etis dan Yuridis Informed Consent. Pustaka Sinar Harapan. Jakarta.

Komalawati, Veronika. 2002. Peranan Informed Consent dalam Transaksi Terapeuti Studi Tinjauan Yuridis. Cetakan Kedua. Citra Aditya Bhakti. Bandung.

Leenen.1996. Pelayanan Kesehatan dan Hukum. (dalam) Danny Wiradharma. Hukum Kedokteran. Binarupa Aksara. Jakarta.

Mertokusumo, Sudikno. 2005. Mengenal Hukum suatu Pengantar. Liberty. Yogyakarta.

Marzuki, Peter Mahmud. 2005. Penelitian Hukum. Kencana Prenada Media Group. Jakarta.

Muchsan. 1981. Peradilan Administrasi Negara. Liberty. Yogyakarta.

Notoatmodjo, Soekidjo. 2010. Etika dan Hukum Kesehatan. Rineka Cipta. Jakarta.

Nurhayanti, Apriana. dan Anita Bustani. 2012. Konsep Kebidanan. Salemba Medika. Jakarta.

Paul Spicker. 1995. Sosial Policy: Themes and Approaches. London: Prentice Hal.
Ridwan, Juniarso dan Achmad Sodik Sudrajat.2010. Hukum Administrasi Negara dan Kebijakan Pelayanan Publik.Nuansa. Bandung.

Saifuddin, Abdul. 2002. Buku Panduan Praktis Pelayanan Kesehatan Maternal Dan Neonatal'. Yayasan Bina Pustaka Sarwono Prawirohardjo. Jakarta.

Soemitro, Ronny H. 1983. Metodologi Penelitian Hukum. Jakarta. Ghalia Indonesia. Jakarta.

Anna, Lusia Kus. Jumlah Dokter di Indonesia Cukup tetapi Menumpuk di Kota Besar. http://health.kompas.com/read/20 16/05/10/093908423/Jumlah.Dokt er.di.Indonesia.Cukup.Tapi.Menu mpuk.di.Kota.Besar. diakses pada tanggal 29 Oktober 2016 jam 11.00 WIB.

Djaelani. 2008. Pelimpahan Kewenangan Dalam Praktik Kedokteran Kepada Perawat.

Bidan Secara Tertulis Dapat Mengeliminasi Tanggung Jawab Pidana \& Perdata. Jurnal Hukum Kesehatan. Ed pertama.

Suharto, Edi. Peta Dan Dinamika Welfare State Di Beberapa Negara: Pelajaran apa yang bisa dipetik untuk membangun Indonesia. http://www. policy. hu/suharto/Naskah\%20PDF/UGM WelfareState. pdf.diakses pada tanggal 29 Oktober 2016 jam 12.00. 